\title{
EDUCATION VALUES AND MORALITY OF THE MAIN CHARACTER IN "THE THEORY OF EVERYTHING" BY JAMES MARSH
}

\author{
Is Mariyani ${ }^{1}$, \\ English Language Education Program, Postgraduate Faculty \\ Universitas Indraprasta PGRI \\ e-mail: is.mariyani@gmail.com ${ }^{1}$
}

\begin{abstract}
This research aims to analyze the values and character building in "The Theory of Everything," to identify the morality of the main character of "The Theory of Everything" 3) the method of value formation, and 4) the implications of using this film in character building and morality in children. This research is done by using a descriptive qualitative method with a literaturebased approach. This research uses content analysis, which analyzes the content of dialogue, scene, and character according to the value of character education and morality of the main character. Based on the result of research, it can be concluded that this film contains 1) the values and character building, such as religious, honesty, tolerance, hard work, creativity, independently, curiosity, nationalism, loving the country, respect for achievement, friendly or communicative, peaceful love, fond of reading, caring society dan responsibility. 2) the moral value of the main character, which is dominant, is as honest, independent, and hard work. 3) the method of value formation through dialogue and very inspirational scenes through the main characters; and 4) the implications of using this film in character building and morality in children is to build self-confidence and selfactualization.
\end{abstract}

Keywords: character education; film analysis; moral values

\section{Introduction}

The mirror of the values of life in the Indonesian child association currently is very apprehensive. We can see how the nation's children speak, behave, and socialize without showing positive values. Children like no longer paying attention to whom they are talking to, acting, and getting along according to their environmental conditions. Value is helpful for humans, both physically and spiritually, because values contain various things that humans need to interact with each other. Value is general instructions going on for a long time that direct behavior and satisfaction in everyday life. Besides, the value can be associated as something valuable, quality, showing quality, and useful for humans. Something that is valuable means that something is valuable or useful for human life.

When we discussed values, they must be connected in character. Everyone has a different character or characteristic and becomes a differentiator between one and another individual. Therefore, people who have a character based on that understanding can make decisions and account for every risk they will receive from their decisions. Two things must be discussed in the theme of character-based education. The first is education, and the second is character. Several educational domains are known in education, such as academic, skills, attitude, and character education (character). Education, according to Article 1, No. 1 (Undang-Undang Republik Indonesia tentang Sistem Pendidikan Nasional, 2003):

Education is a conscious and planned effort to create a learning atmosphere and learning process so that students actively develop their potential to have religious-spiritual strength, self-control, personality, intelligence, noble character, and skills needed by themselves, society, nation, and country.

Education can also be referred to as an effort of the community and nation in preparing its young generation for the survival of the lives of the people and the nation to be better in the future. Sustainability is 


\section{INFERENCE: Journal of English Language Teaching}

Vol. 4, No. 3, December 2021 - March 2022

p-ISSN: 2615-8671

e-ISSN: 2615-868X

characterized by cultural inheritance and a national character to be better in the future. In cultural and national character education, students actively develop their potential, carry out internalization processes, and appreciate values to become their personalities in socializing in society, developing the lives of more prosperous and dignified people.

The following discussion is a character. Education is no longer concerned with value but also character building. Character education is considered to have a strategic function for the progress of the nation. So far, there has been no encouragement that can unite the people with the government. Believed to be with national character education, this can be built. The government has identified 18 values developed in character education (Syarbini, 2012, hal. 26): Religious, Honesty, Tolerance, Discipline, Hard Work, Creative, Independent, Democratic, Curiosity, Nationality, Loving the Country, appreciating achievement, Friendly/communicative, Loving Peace, Love Reading, caring for the environment, Caring for the social, and Responsibility. The process of building values is not only through formal and non-formal education.

Nevertheless, along with the development of science and technology, educational values can be planted through other educational media, both print and electronic mass media such as audio, visual, and audio-visual media. One of the practical and acceptable communication media for all layers of society is film. Although there are many adjustments to be made when immersing local culture and school curriculum (Engliana et al., 2020, 2021; Harini, 2018; Nurjanah et al., 2018; Suhaidi, 2013), it is possible if the adaptations of the carefully selected local culture are incorporated in their local environmental settings (Miranti et al., 2018). Films can also be a medium for foreign language students to study linguistic issues, such as the use of language in contexts (Hahn, 2014), understanding maxims (Tmasia \& Serly, 2018), and cultural aspects of language (Ismaili, 2013).

The film can attract people's attention and partly realized because the film can deliver messages uniquely. The film always influences and shapes society based on the message content behind it. The film continuously records reality that grows and develops in society and then projects it onto the screen. The purpose of displaying the moral aspect in the film is to attract more audience interest and give an idea of how good values of life should be applied by humans who have civilized, cultural, sensible, thoughtful, and Godly dignity (Samuelson, 2008; Tappan, 1998). Moral aspects also include essential aspects that students must learn in addition to studying the main subjects. One of the films containing the values of character and moral education is "The Theory of Everything" (Marsh, 2014). The film, directed by James Marsh, tells the story of the life journey of the famous physicist Steven Hawking.

\section{Method}

The data source in this study is the film "The Theory of Everything." this research was designed using a descriptive qualitative approach. The data analyzed is data in the form of words and images in the film The Theory of Everything to reveal the value of character education contained in the film. The data obtained will be analyzed descriptively to better explain the value of character education in detail by using the theory put forward by Syarbini (2012, hal. 26) that researchers have described on a theoretical basis. From the analysis results, it is expected that there will be an evaluation of the value of character education in the film "The Theory of Everything" to be further examined whether the film is suitable for Indonesian children to shape their character. This research paradigm uses descriptive qualitative research; in this position, researchers are the main instrument (Sugiyono, 2009). The researcher in data analysis takes several steps:

1. Watch the movies several times to get the character education values contained in them.

2. Presenting the data obtained by categorizing the values obtained based on the values developed in character education in the center of the curriculum and books of the Ministry of National Education.

3. Draw conclusions based on the findings obtained.

\section{Results and Discussion}

\section{The Values of Character Education}

The writer collected 122 pieces of data that contain character education values in the film. Fifteen values of character education have been found in this film. The following is a description of each of these values: 
Table 1. Sample of Religious Values

\begin{tabular}{cl}
\hline Scene & \multicolumn{1}{c}{ Dialogue } \\
\hline $00: 03: 37-00: 03: 38$ & Cof E, Church of England \\
\hline $00: 12: 40-00: 12: 42$ & In Sunday Finery, Jane peels off from her family... \\
\hline 00:14:07 - 00:14:09 & Sounds less of an argument against God than against physicists \\
\hline 01:06:23 - 01:06:27 & $\begin{array}{l}\text { If the world were all potatoes, easy- you could trace a precise } \\
\text { beginning, as Stephen once did, a moment of Creation. } \\
\text { Hallelujah, God lives. }\end{array}$ \\
\hline $01: 13: 33-01: 13: 35$ & Everyone is gathered for the Christening Party. \\
\hline
\end{tabular}

Religious is an attitude and behavior that is obedient in carrying out the teachings of the religion it adheres to, tolerant of the implementation of worship of other religions, and living in harmony with those of other religions. In this film, we can see several scenes and Dialogueues that have been presented previously by the author that some figures appear very religious. As in the scene where Jane said that she was part of the Church of England congregation, in other words, she said that she was a person who was obedient to God. Besides, there is a scene where Stephen waits for Jane and her family, who are on Sunday at the church.

\section{Honest}

Table 2. Sample Dialogue of Honesty Value

\begin{tabular}{cl}
\hline \multicolumn{1}{c}{ Scene } & \multicolumn{1}{c}{ Dialogue } \\
\hline $00: 02: 44-00: 02: 46$ & He's strange, clever, goes on Ban, The Bomb marches \\
\hline $00: 03: 16-00: 03: 18$ & $\begin{array}{l}\text { Stephen: "Science" } \\
\text { Jane: "Arts" }\end{array}$ \\
\hline $00: 03: 25-00: 03: 29$ & \begin{tabular}{l} 
Cosmologist \\
\hline $00: 03: 37-00: 03: 38$
\end{tabular} \\
\hline Cof E, Church of England \\
\hline $00: 04: 19-00: 04: 21$ & $\begin{array}{l}\text { My Finals papers were such a shamble the examiners called me } \\
\text { in for a 'Viva' and I told them }\end{array}$ \\
\hline $00: 08: 17-00: 08: 19$ & A mildly terrifying face-to-face thingy, and interrogation \\
\hline $00: 10: 05-00: 10: 06$ & None. I was going do them later \\
\hline $00: 13: 12-00: 13: 15$ & I could only nine \\
\hline $00: 28: 16-00: 28: 17$ & Arts, Language, poetry. I'm thinking of doing a Ph.D. eventually. \\
\hline $01: 13: 05-01: 13: 07$ & I have a disease, Bri \\
\hline
\end{tabular}

Honest is a behavior based on efforts to make himself a person who can always be trusted in words, actions, and work. In this film, we can find many scenes and dialogues that show the value of honesty. No matter the truth, the characters in this film always tell the truth.

In the first scene of meeting Jane and Stephen, Jane's best friend said honest things about Stephen, "He's strange, clever, go on Ben, The Bomb Marches." Then Jane and Stephen unhesitatingly acquainted and told each person their fields. Jane likes arts, Stephen has science and religion, Jane is a Christian, and Stephen is a cosmologist who doesn't believe in God. 
INFERENCE: Journal of English Language Teaching

Vol. 4, No. 3, December 2021 - March 2022

p-ISSN: 2615-8671

e-ISSN: 2615-868X

Tolerance

Table 3. Sample Dialogue of Tolerance Value

\begin{tabular}{cl}
\hline Scene & \multicolumn{1}{c}{ Dialogue } \\
\hline 00:03:52 - 00:03:54 & Jane, now listening intently to Stephen \\
\hline 00:12:35 - 00:12:37 & $\begin{array}{l}\text { Stephen is now sitting on a stone wall, waiting as - the wilds emerge, in the } \\
\text { Sunday Finery. }\end{array}$ \\
\hline 00:13:36 - 00:13:37 & Will you try my elderflower wine? Yes, please \\
\hline 01:05:32 - 01:05:35 & $\begin{array}{l}\text { No God? Really? Fascinating. Because I'd understood you'd proven the } \\
\text { need for a Creator. My mistake. }\end{array}$ \\
\hline
\end{tabular}

Attitudes and actions that different value religions, ethnic groups, opinions, attitudes, and acts are different from others. In this film, various kinds of tolerance values are shown. The scene where Jane first met Stephen and Stephen told her about her life at Oxford, and Jane seemed to enjoy and want to listen to Stephen's whole story even though science is not a field of Jane. Then the scene when Stephen had to wait for Jane outside the church when Jane and her family were on Sunday worship in the Church of England showed a deep tolerance value for allowing others to worship according to the religion and beliefs that she embraced.

Hard Working

Table 4. Sample Dialogue of Hard-working Value

\begin{tabular}{|c|c|}
\hline Scene & Dialogue \\
\hline 00:01:16 - 00:01:18 & $\begin{array}{l}\text { Stephen Hawking (in his early 20s) and his friend Brian (same age) } \\
\text { race each other recklessly through the Narrow, }\end{array}$ \\
\hline 00:06:13 - 00:06:15 & Full, give me twenty-one, drivel-two, drivel-three, ... \\
\hline 00:12:02 - 00:12:05 & $\begin{array}{l}\text { Stephen looks around at the empty Lab. He goes to the Blackboard, } \\
\text { picks up a piece of chalk. Look at the blank board, but then puts the } \\
\text { Chalk back down and then begins to study, with Rapt awe, the } \\
\text { ancient laboratory equipment }\end{array}$ \\
\hline 00:20:05 - 00:20:07 & $\begin{array}{l}\text { Sciama and Stephen and Physicists 1,2, and } 3 \text { arrive late on the } \\
\text { platform. The train is already pulling in. Sciama and the other three } \\
\text { all run for it. }\end{array}$ \\
\hline $00: 22: 50-00: 22: 53$ & Stephen at the blackboard makes a dot on the blackboard, \\
\hline $00: 23: 11-00: 23: 13$ & $\begin{array}{l}\text { Stephen writes, inspired, formula on the famous blackboard. He } \\
\text { stops, thinks, continuous, then deletes a bit, and writes again, faster, } \\
\text { faster, his mind racing, even as his fingers begin to betray him, } \\
\text { growing weaker, weaker... }\end{array}$ \\
\hline $00: 24: 50-00: 24: 52$ & Stephen struggles to bring his little finger to meet his thumb \\
\hline $00: 33: 36-00: 33: 39$ & $\begin{array}{l}\text { Stephen aims, hits his ball through the first hoop, then walks, as best } \\
\text { he can, off toward his ball }\end{array}$ \\
\hline $00: 39: 15-00: 39: 17$ & Stephen slides on his back, down the stairs, dressed in a suit \\
\hline $00: 43: 35-00: 43: 36$ & $\begin{array}{l}\text { Stephen tries to pull himself up the stairs by the spoke of the } \\
\text { balustrade. It takes him many seconds just to get up the first stairs. }\end{array}$ \\
\hline $00: 44: 23-00: 44: 25$ & Stephen is only halfway up the stairs, using his last heroic energies. \\
\hline 00:55:47 - 00:55:49 & Jane, at the table, trying to work on her thesis. \\
\hline $01: 49: 38-01: 49: 40$ & $\begin{array}{l}\text { He wants to go and pick up that fallen cap. Miraculously, the } \\
\text { muscles in his slackened face start to stir }\end{array}$ \\
\hline
\end{tabular}

The value of hard work is behavior that shows genuine effort in overcoming various learning obstacles and tasks and completing tasks as well as possible. The first scene showed that the hardworking 
figures were when Stephen and Brian referred to their bicycles to reach their destination, especially when they were in a rowing competition, where both Stephen and the team worked hard to win.

Turning to another scene, when Stephen was in a lab, Albert Einstein to find a new theory about the universe. On the way to the conference, Professor Sciama, Stephen, and several of his friends were trying hard to reach the departing train. Stephen tried hard to learn and find formulas from previous scientists to find a new formula to complete his dissertation. After that, in the scene, Stephen describes a point and strives to find a new theory about the universe, making Stephen has to formulate formula by formula, formula by formula, and theory after theory.

\section{Creative}

Table 5. Sample Dialogue of Creative

\begin{tabular}{|c|c|}
\hline Scene & Dialogue \\
\hline $00: 15: 26-00: 15: 28$ & The old family Punning game has begun \\
\hline 00:20:47 - 00:20:48 & Stephen smiles- seeing his future revealed \\
\hline $00: 22: 50-00: 22: 52$ & Stephen at the blackboard makes a dot on the blackboard \\
\hline $00: 23: 11-00: 23: 13$ & $\begin{array}{l}\text { Stephen writes, inspired, formula on the famous blackboard. He } \\
\text { stops, thinks, continuous, then deletes a bit, and writes again, } \\
\text { faster, faster, his mind racing, even as his fingers begin to betray } \\
\text { him, growing weaker, weaker... }\end{array}$ \\
\hline $00: 41: 25-00: 41: 27$ & Prove it. Prove with a single equation that time has a beginning. \\
\hline $00: 49: 11-00: 49: 13$ & I've got an idea. I've got an idea, Jane! \\
\hline
\end{tabular}

Creativity is thinking and doing something to produce new ways or results from something that has been owned. In a family lunch scene, it appears that Stephen's family is a creative family by playing new and fresh games to add intimacy. Besides, in a scene where Stephen describes a black spot on the board, it appears that Stephen is creating a new way to explain black holes.

Independent

Table 6. Sample Dialogue of Independent Value

\begin{tabular}{|c|c|}
\hline Scene & Dialogue \\
\hline $00: 24: 50-00: 24: 52$ & Stephen struggles to bring his little finger to meet his thumb \\
\hline $00: 33: 36-00: 33: 38$ & $\begin{array}{l}\text { Stephen aims, hits his ball through the first hoop, then walks, as best } \\
\text { he can, off toward his ball }\end{array}$ \\
\hline $00: 39: 15-0: 39: 17$ & Stephen slides on his back, down the stairs, dressed in a suit \\
\hline $00: 39: 35-00: 39: 38$ & $\begin{array}{l}\text { Stephen walks with great difficulty up the hallway, using (for the first } \\
\text { time) two walking sticks }\end{array}$ \\
\hline $00: 43: 35-0: 43: 37$ & $\begin{array}{l}\text { Stephen tries to pull himself up the stairs by the spoke of the balustrade. } \\
\text { It takes him many seconds just to get up the first stairs }\end{array}$ \\
\hline $00: 48: 22-0: 48: 24$ & Stephen struggles to pull on the pyjama himself \\
\hline $01: 35: 20-01: 35: 22$ & In a quiet moment, Stephen sits alone, trying out the new device \\
\hline 01:36:49 - 01:36:51 & Stephen, alone, continuous to write, one painstaking word at a time \\
\hline
\end{tabular}

There is no doubt that this film so much illustrates the value of independence. Independent is attitudes and behaviors that are not easily dependent on others in completing tasks. In the initial scene, it was said that Stephen wanted to apply for a job to support himself. Then, when Stephen struggled to move his finger without the help of others, Stephen tried hard to hit the ball without Jane's help. We can also see that Stephen tried to be independent through the scenes; he climbed the stairs despite difficulties, and without doubt, Stephen's independence when he had to walk alone using his two sticks. Also, there are scenes where Stephen tries to wear his sleeping pajamas because Jane has to take care of their child. 
INFERENCE: Journal of English Language Teaching

Vol. 4, No. 3, December 2021 - March 2022

p-ISSN: 2615-8671

e-ISSN: 2615-868X

Curiosity

\begin{tabular}{|c|c|}
\hline Scene & Dialogue \\
\hline 00:02:37 - 00:02:39 & Who is that guy? \\
\hline 00:03:23 - 00:03:25 & So, what do you think? \\
\hline 00:03:48 - 00:03:50 & So, what do cosmologists worship then? \\
\hline 00:04:16 - 00:04:18 & Why didn't you stay at Oxford? \\
\hline 00:04:26 - 00:04:27 & What's a viva? \\
\hline 00:08:15 - 00:08:17 & How many of Sciama's questions have you done? \\
\hline 00:07:14 - 00:07:15 & What's the probability? \\
\hline 00:10:56 - 00:10:57 & Any ideas? \\
\hline 00:12:00 - 00:12:02 & $\begin{array}{l}\text { Stephen looks around at the empty Lab. He goes to the blackboard, picks } \\
\text { up a piece of chalk, looks at the blank board, but then puts the Chalk } \\
\text { back down and then begins to study, with Rapt awe, the ancient } \\
\text { laboratory equipment }\end{array}$ \\
\hline $00: 17: 26-00: 17: 28$ & What particular time period do you visit? \\
\hline $00: 21: 34-00: 21: 36$ & $\begin{array}{l}\text { Stephen is silently staring down at the circulating coffee in front of him } \\
\text { I wonder what would happen if I... }\end{array}$ \\
\hline $00: 21: 52-00: 21: 52$ & If you applied Penrose's theory about black holes to the entire universe? \\
\hline 00:20:00 - 0:20:02 & $\begin{array}{l}\text { If- if-so-if Einstein is right, if general relativity is correct, then the } \\
\text { universe is expanding, yes? }\end{array}$ \\
\hline 00:25:02 - 0:25:04 & What is it? What's wrong with me? \\
\hline 00:26:45 - 00:26:47 & Wait! What about the brain? \\
\hline 00:40:57 - 0:40:58 & A spacetime singularity? \\
\hline 00:41:37 - 00:41:39 & $\begin{array}{l}\text { Wouldn't that be nice, Professor? One single elegant equation to } \\
\text { explain everything? }\end{array}$ \\
\hline 00:55:12 - 00:55:15 & $\begin{array}{l}\text { Idon't get it. You've spent years assuming black holes exist-you believe } \\
\text { Cygnus X-1 will turn out to be the first black hole we can actually } \\
\text { observe, and you yet you bet Kip Thorne that it isn't a black hole? }\end{array}$ \\
\hline 01:05:02 - 01:05:04 & You no longer believe in the creation? \\
\hline 01:13:05 - 01:13:07 & Does it make a difference? \\
\hline 01:48:05 - 01:48:06 & Is time travel possible \\
\hline 01:49:37 - 01:49:39 & $\begin{array}{l}\text { You have said you do not believe in God. Do you have a philosophy of } \\
\text { life that helps you? }\end{array}$ \\
\hline
\end{tabular}

Curiosity is an attitude and behavior that seeks to know more deeply and expand from what is known, seen, heard. In this film, there are many findings for the value of curiosity. A documentary about a physics scientist is indeed very thick about the value of curiosity. It starts in the first scene when Jane wants to meet Stephen, and he finds out by asking his friend. Then without further ado, they get to know more by asking more in-depth questions about their respective fields at the university, religion, and interests. Turning to the next scene, how was Brian curious about how many questions Prof. Sciama, which was completed by Stephen, and when Stephen asked about the possibilities that happened to the theory of time and black holes, seemed to describe the curiosity of a scientist.

Nationality

Table 8. Sample Dialogue of Nationality

\begin{tabular}{cc}
\hline Scene & Dialogue \\
\hline 01:56:46 - 01:56:48 & Stephen declined the offer of a knighthood from the Queen \\
\hline
\end{tabular}

The spirit of nationality is a way of thinking, acting, and insight that places the interests of the nation and the state above themselves and their groups. Stephen shows this value in his rejection of the title of the knight that Queen Elizabeth II wanted to pin on her. Stephen prefers to conduct continuous research for many people rather than get a knighthood and stop doing research. 


\section{Loving Country}

Table 9. Sample Dialogue of Loving Country Value

\begin{tabular}{cc}
\hline Scene & Dialogue \\
\hline 00:20:05 - 00:20:07 & As the whistle along, English countryside in the background \\
\hline 01:35:04 - 01:35:06 & It's American! Oh, my Goodness, are there any other voices? \\
\hline 01:52:57 - 01:52:59 & In Empire room, Buckingham palace \\
\hline
\end{tabular}

A loving country is a way of thinking, acting, and acting that shows loyalty, caring, and a high appreciation for the nation's language, physical, social, cultural, economic, and political environment. The first scene in the film, starting with the British national anthem, suggests that the film is full of the meaning of love for their homeland. Also, in a scene where Stephen gets a new device that can help him speak, Stephen loudly says he wants a sound with a British accent instead of an American. In addition to this, the film was closed with their presence at Buckingham Palace, which became the most important symbol for their homeland. So, it can be ascertained that this film has the value of the love of a great homeland.

\section{Appreciating Achievement}

Table 10. Sample Dialogue of Appreciating Achievement

\begin{tabular}{cl}
\hline \multicolumn{1}{c}{ Scene } & \multicolumn{1}{c}{ Dialogue } \\
\hline 00:11:03 --> 00:11:05 & Well, I see. Well, thank God. Well done Stephen \\
\hline 00:06:39 --> 00:06:41 & $\begin{array}{l}\text { Rowdy tables of graduates and undergraduates and rowers, males and } \\
\text { females. Beer flows. }\end{array}$ \\
\hline 00:41:01 - 00:41:04 & $\begin{array}{l}\text { Brilliant. It's a brilliant Stephen. So all that remains to be said is. well } \\
\text { done. Or should I say, well done Doctor. And extraordinary theory }\end{array}$ \\
\hline 00:42:19- 00:42:22 & $\begin{array}{l}\text { A celebrational dinner party, attended by Jane, Brian, Ellis, Rees, } \\
\text { Carter, and two of their girlfriends. Jane rises to give a toast }\end{array}$ \\
\hline 00:49:37 - 00:49:39 & Good Luck \\
\hline 01:48:01 - 01:48:04 & $\begin{array}{l}\text { But it's been - really - one of the great joys of my life to watch this } \\
\text { man defy every expectation, both scientific and personal. So, it's with } \\
\text { no small pride that I ask him to return to the stage once more. }\end{array}$ \\
\hline 01:52:12 - 01:52:14 & Applause, standing ovation \\
\hline 01:54:05 - 01:54:07 & Congratulations - my companion - of Honour. \\
\hline $01: 54: 32-01: 54: 34$ & Thank you. For today. It's been extraordinary. \\
\hline
\end{tabular}

Appreciating achievement is an attitude and action that encourages him to produce something useful for the community and recognizes and respects the success of others. This film shows several times how to appreciate achievement, whether done by yourself or others. In the scene when Stephen succeeded in working on the questions given by Sciama, although he could only work on nine questions, Sciama still appreciated Stephen by saying, "Well done, Stephen." Besides, when they won the rowing competition, they all celebrated victory in a cafe and everyone took part in the celebration of the victory. Then, the award was also seen when Stephen managed to face his trial to get a Doctorate. The examiners, especially Prof. Sciama, congratulated, and the friends celebrated Stephen's success by having dinner together at Stephen's house. 
INFERENCE: Journal of English Language Teaching

Vol. 4, No. 3, December 2021 - March 2022

p-ISSN: 2615-8671

e-ISSN: 2615-868X

Friendly/Communicative

Table 11. Sample Dialogue of Friendly/Communicative Values

\begin{tabular}{cl}
\hline Scene & Dialogue \\
\hline 00:02:00 - 00:02:01 & $\begin{array}{l}\text { Jane nods, as Diana goes over to greet the boy and then walk off } \\
\text { together with him into the crowd. }\end{array}$ \\
\hline 00:07:16 - 00:07:18 & $\begin{array}{l}\text { He smiles at her; the others look back and forth between Jane and } \\
\text { Stephen. Jane parks up, interested }\end{array}$ \\
\hline 00:13:03 - 00:13:05 & $\begin{array}{l}\text { Sunday family lunch. A noisy, eccentric, bohemian atmosphere } \\
\text { 00:42:37 - 00:42:40 }\end{array}$ \\
\hline $\begin{array}{l}\text { As the conversation turns into a hubbub of chatter, Stephen, smiling, } \\
\text { drop his fork. Jane, in the conversation now with one of the girlfriends. }\end{array}$ \\
\hline $\begin{array}{l}\text { After the rehearsal, the Choir file past Jane. Jonathan recognizes her at } \\
\text { once. }\end{array}$ \\
\hline $\begin{array}{l}\text { My chances are probably-well, some "integer of zero, " but I think we } \\
\text { can make a go of this. I want us to be together for as long as we got. } \\
\text { And if that's not very long then- well, that's just how it is. It will have to } \\
\text { do. }\end{array}$
\end{tabular}

Friendly or communicative is an action that shows pleasure in talking, associating, and collaborating with other people - the characters in this film show much friendship and communicative values. At the beginning of the meeting, we can see how Jane and Stephen opened themselves to communication, then continued with the scene of Stephen's family, who happily accepted Jane as a guest but still showed warm and friendly behavior so that Jane looked very comfortable in the family.

Loving Peace

Table 12. Sample Dialogue of Loving Peace Value

\begin{tabular}{|c|c|}
\hline Scene & Dialogue \\
\hline $00: 27: 41-00: 27: 43$ & Wagner is playing incredibly loudly on an old tape-deck \\
\hline $00: 33: 36-00: 33: 38$ & Stephen? Let me in. Please. \\
\hline 00:35:03 - 00:35:05 & I think-I've fallen in love with you \\
\hline $00: 37: 35-00: 37: 38$ & $\begin{array}{l}\text { I know-I know what you all think. That I don't look a terribly strong } \\
\text { person. But I love him. And he loves me. We're going to fight this } \\
\text { illness- all of us. }\end{array}$ \\
\hline 00:50:18 - 00:50:20 & $\begin{array}{l}\text { Jane then approaches Stephen nervously. But when he looks up at } \\
\text { her, his eyes are blazing with light and passion-this pulls her out of } \\
\text { her sadness }\end{array}$ \\
\hline 01:00:18 - 01:00:20 & $\begin{array}{l}\text { I'd like to make a suggestion, it might sound unusual, but I've seen } \\
\text { it work wonders. I think you should consider-joining the church } \\
\text { choir }\end{array}$ \\
\hline 01:02:30 - 01:02:32 & If you're not in the mood, we could absolutely forget \\
\hline 01:09:51 - 01:09:53 & $\begin{array}{l}\text { I understand you need more help. And if there is - someone-who is } \\
\text { prepared to offer it -I won't object, as long as you continue to love } \\
\text { me. }\end{array}$ \\
\hline 01:13:06 - 01:13:07 & Of Course, not \\
\hline $01: 14: 15-01: 14: 18$ & $\begin{array}{l}\text { I've always supported you in your choice not to have home help, but } \\
\text { now, you need a permanent solution. This-current "solution" can't } \\
\text { go on. You need a proper live-in nurse immediately. }\end{array}$ \\
\hline
\end{tabular}

Love for peace is the attitude, words, and actions that cause other people to feel happy and safe in their presence. Based on the data that the author has described before, we can see the scene where Stephen likes Wagner's music, which can calm him down. Then, the scene where Jane tried hard to get into Stephen's boarding room to give moral support to Stephen, who had been convicted of a severe illness. Jane tries to make and convince Stephen that she has her and does not need to worry about the illness because Jane promised to fight the disease together. 
INFERENCE: Journal of English Language Teaching

Vol. 4, No. 3, December 2021 - March 2022

p-ISSN: 2615-8671

e-ISSN: 2615-868X

Love Reading

\begin{tabular}{cl}
\multicolumn{1}{c}{ Table 13. Sample Dialogue of Love Reading Value } \\
\hline \multicolumn{1}{c}{ Scene } & \multicolumn{1}{c}{ Dialogue } \\
\hline 00:05:44 --> 00:05:45 & $\begin{array}{l}\text { Stephen reads a chess book that lies on his Lap out of sight under the } \\
\text { table }\end{array}$ \\
\hline 00:05:46 --> 00:05:47 & $\begin{array}{l}\text { Stephen crumples the paper in his pocket and continues to read the } \\
\text { Chess book }\end{array}$ \\
\hline 00:22:00 --> 00:22:02 & $\begin{array}{l}\text { If- if-so-if Einstein is right, if general relativity is correct, then the } \\
\text { universe is expanding, yes? }\end{array}$ \\
\hline 00:27:54 --> 00:27:57 & $\begin{array}{l}\text { Stephen in the corner, in his pajamas, his mattress now on the floor } \\
\text { (rather than on the high bunk as before) legs drawn up, reading a } \\
\text { book of chess. }\end{array}$ \\
\hline
\end{tabular}

Loves to read, which is the habit of providing time to read various readings that give virtue to him. Although there are not too many scenes that show that there is value in reading this film, we can know that Stephen is a genius who knows various kinds of theories from physicists about physics and the universe. However, several scenes show that Stephen prefers to read chess books in the middle of lectures and free time. Thus, in this film, there is still value in reading.

Caring for Society

Table 14. Sample Dialogue of Caring for Society

\begin{tabular}{|c|c|}
\hline Scene & Dialogue \\
\hline $00: 17: 44-00: 17: 46$ & $\begin{array}{l}\text { Jane takes the champagne; Stephen has just chosen and pours } \\
\text { half of his into her glass }\end{array}$ \\
\hline $00: 35: 57-00: 35: 59$ & She takes the glasses off, cleans them on her dress. \\
\hline $00: 39: 31-00: 39: 33$ & $\begin{array}{l}\text { Stephen smiles, gently shakes his head. She gives him his two } \\
\text { walking sticks }\end{array}$ \\
\hline 00:39:42 - 00:39:44 & She puts an extra pillow behind him \\
\hline $00: 53: 14-00: 53: 16$ & Brian lifts Stephen out of his chair. \\
\hline 01:04:35 - 01:04:36 & Jonathan picks up Stephen's fork, spears a cube of steak \\
\hline 01:07:42 - 01:07:43 & Jonathan helps Stephen sip his coffee \\
\hline 01:08:43 - 01:08:45 & $\begin{array}{l}\text { If there was anything, I can do. To be service. To you, your family. } \\
\text { I have no children, no commitments. If I could help you, I believe } \\
\text { I would find a purpose that would alleviate my own situation. It } \\
\text { would be a privilege. }\end{array}$ \\
\hline $01: 11: 24-01: 11: 25$ & Hawking bathroom, Jonathan takes Stephen to the toilet \\
\hline 01:10:43 - 01:10:44 & Jonathan cradles Stephen as they sit there and look out to sea \\
\hline 01:19:04 - 01:19:06 & $\begin{array}{l}\text { Jonathan opens the two beer bottles, tucks his handkerchief under } \\
\text { Stephen's chin }\end{array}$ \\
\hline
\end{tabular}

Care for social is attitudes and actions that always want to assist other people and people in need. In this film, there are many values of social care, like when Stephen gave half his beer to Jane, who wanted to drink wine. Then when Sciama wanted to help Stephen walk, Stephen refused and preferred to walk alone with the help of his two sticks. In another scene, when Brian celebrates Stephen's success, Brian voluntarily holds Stephen to climb onto the statue with his friends and leaves his wheelchair. Also, in the scene where Jonathan helps Stephen cut the steak, he is eating, stirring the coffee he drinks, one scene shows social care. 
INFERENCE: Journal of English Language Teaching

Vol. 4, No. 3, December 2021 - March 2022

p-ISSN: 2615-8671

e-ISSN: 2615-868X

Responsible

Table 15. Sample Dialogue of Responsible Value

\begin{tabular}{cl}
\hline Scene & \multicolumn{1}{c}{ Dialogue } \\
\hline 00:09:10 - 00:09:12 & $\begin{array}{l}\text { He then starts to write on pad, rapidly, effortlessly, the calculations } \\
\text { pouring out of him, his writing hand adroit and swift }\end{array}$ \\
\hline 00:37:35 - 00:37:37 & $\begin{array}{l}\text { I know- I know what you all think. That I don't look a terribly strong } \\
\text { person. But I love him. And he loves me. We 're going to fight this illness- } \\
\text { all of us. }\end{array}$ \\
\hline 00:39:27 - 00:39:29 & $\begin{array}{l}\text { Jane is there to meet him, to help him to his feet, to straighten his bowtie } \\
\text { 00:48:18 - 00:48:20 }\end{array}$ \\
\hline $\begin{array}{l}\text { The new baby's cries carry from upstairs. Jane runs out to go to the } \\
\text { baby } \text { rup the stairs. }\end{array}$ \\
\hline $\begin{array}{l}\text { Robert and Jane, together, with great difficulty, get Stephen into the front } \\
\text { seat and shut the door. Robert struggles to collapse the wheelchairs, } \\
\text { until Jane comes and together, they muscle it onto the Roof-rack }\end{array}$ \\
\hline $\begin{array}{l}\text { Stephen must live! You have to bring him round from the anesthetic } \\
\text { 01:25:13 - 01:25:15 }\end{array}$ \\
$\begin{array}{l}\text { A surgeon prepares to perform a tracheotomy on Stephen, marking the } \\
\text { spot on his neck, the marker pen. }\end{array}$
\end{tabular}

Responsibility is the attitude and behavior of a person to carry out the duties and obligations that he should do to himself, society, environment (nature, social, and culture), State, and God Almighty. In this film, several scenes show that some of the characters in this film are very responsible. As in the scene when Stephen first learned that he had an illness, he still wanted to research to complete his studies. Then, when Jane learned of Stephen's illness, Jane did not run away but met Stephen's father and said that he was willing to accompany Stephen in fighting his illness. After becoming a wife, Jane was hugely responsible for her husband. Not only responsible for Stephen, but Jane is also responsible for her child. The scene where Jane runs upstairs because her baby is crying is a form of responsibility that Jane has.

\section{The Moral Values in The Main Character}

Table 16. Moral Values Found in the Film

\begin{tabular}{ll}
\hline Morality & \multicolumn{1}{c}{ Dialogue } \\
\hline & $\begin{array}{l}\text { Stephen: "Science" } \\
\text { Jane: "Arts" }\end{array}$ \\
\hline Cosmologist \\
\hline My Finals papers were such a shamble the examiners called me in for a 'Viva', \\
and I told them
\end{tabular}


Stephen struggles to pull on the pyjama himself

In a quiet moment, Stephen sits alone, trying out the new device

Stephen, alone, continuous to write, one painstaking word at a time

Stephen looks around at the empty Lab. He goes to the Blackboard, picks up a piece of chalk. Look at the blank board, but then puts the Chalk back down and then begins to study, with Rapt awe, the ancient laboratory equipment

Sciama and Stephen and Physicists 1,2, and 3 arrive late on the platform. The train is already pulling in. Sciama and the other three all run for it.

Stephen at the blackboard makes a dot on the blackboard,

Stephen writes, inspired, formula on the famous blackboard. He stops, thinks, continuous, then deletes a bit, and writes again, faster, faster, his mind racing, even as his fingers begin to betray him, growing weaker, weaker...

Hard Working Stephen struggles to bring his little finger to meet his thumb

Stephen aims, hits his ball through the first hoop, then walks, as best he can, off toward his ball

Stephen slides on his back, down the stairs, dressed in a suit

Stephen tries to pull himself up the stairs by the spoke of the balustrade. It takes him many seconds just to get up the first stairs.

Stephen is only halfway up the stairs, using his last heroic energies.

He wants to go and pick up that fallen cap. Miraculously, the muscles in his slackened face start to stir

Stephen put the baby from Jane

Stephen played with the children using a wheelchair

Stephen listened to the explanation about his disease, and he was a little bit upset, but he listened calmly

Patient

Stephen walked with two sticks, met another Professor, and asked some

Optimistic questions to finish his dissertation.

1) Honest

In various scenes and conversations, the author can conclude that Stephen is an honest person and is forthright. Although his friends initially doubted Stephen, Stephen still tried not to hide anything from his friends and wife. As in a conversation with Jane, Stephen unhesitatingly said that he was a cosmologist who did not believe in God.

2) Independent

Undoubtedly Stephen's independence as an individual, before his illness worsened, Stephen was an independent person. In various scenes, we can see that several times Stephen tried to climb the ladder alone, even though his legs were paralyzed and unable to walk.

3) Hard work

In various scenes, it can be seen that Stephen always works hard to do everything independently. Not only that, in the academic field, Stephen always works hard to find something new in the world of scientists. So, it is not surprising if Stephen can find various new theories and become a famous scientist until the end of his life.

4) Love the Family

Happy family portraits are always displayed in several movie scenes. Despite all its limitations, Stephen always tries to make his children happy by playing together. In a scene, Stephen tries to play with his children in a wheelchair; besides, Stephen seems eager to carry his baby, even though it is difficult.

5) Steadfast 


\section{INFERENCE: Journal of English Language Teaching}

Vol. 4, No. 3, December 2021 - March 2022

p-ISSN: 2615-8671

e-ISSN: 2615-868X

Suffering from a rare disease that can destroy his life made Stephen feel pessimistic about survival. Nevertheless, he tried to be steadfast in living everything. Moreover, Jane is always nearby to continue giving her support and proven even though Stephen can still survive until he is 82 years old in minimal circumstances.

6) Optimism

Overall, this film conveys the optimism of Stephen Hawking in working in his field despite having weaknesses in his illness. Stephen Hawking always thinks positively and continues to be optimistic about continuing to survive and complete all his theories. Even though he was paralyzed, Stephen could write dozens of books on physics theory for the world.

\section{Conclusions}

Based on the research carried out by the author in James Marsh's film The Theory of Everything, the writer can present several conclusions as follows:

1. This film contains 15 types of character education values from a total of 18 -character values referred to in the citation of the national education curriculum developed by the national education system, with 122 findings. The types of character values, along with the presentation of the number of character values contained in this film, are as follows: Religious as many as five findings (4.09\%), Honest as many as 11 findings $(9.02 \%)$, Tolerance as much as four findings (3.28\%), Hard work as many as 13 findings $(10.65 \%)$, creativity value as many as six findings $(4.92 \%)$, Independent as many as eight findings $(6.56 \%)$, curiosity 22 findings $(18.03 \%)$, national spirit as much as one finding $(0.82 \%)$, love for the homeland as many as three findings $(2.46 \%)$, respecting achievements nine findings $(7.38 \%)$, friendly or communicative as many as seven findings (5.74\%), peace of mind as many as 11 findings (9.02\%), likes to read four findings $(3.28 \%)$, social care 11 findings $(9.02 \%)$ and responsibility for seven findings $(5.73 \%)$.

2. The dominant moral value of the main character is good morality, which is honest, independence, hard work, a loving family, and optimism about being able to continue to reach his goals despite a limitation. The percentage values are as follows: Honest as many as seven findings $(23.33 \%)$, Independent as many as seven findings (23.33\%), Hard Work as many as ten findings (33.33\%), Love Family as much as two findings $(6.69 \%)$, Steadfast with one finding (3.33\%), Optimistic as many as one finding (3.33\%). While for bad morals, only found two values, namely godless as much as one finding (3.33\%) and violating the rules as much as one finding (3.33).

The method of forming values of character and moral education in the "Theory of Everything" film through Dialogues and scenes that are very inspiring to the audience by presenting the main character who has physical limitations but is not limited to dreams, giving an example and appreciation, giving self-confidence and hard work.

\section{References}

Engliana, Dwiastuty, N., Miranti, I., \& Nurjanah, N. (2020). Penguatan pendidikan karakter melalui cerita rakyat pada pembelajaran Bahasa Inggris di perguruan tinggi. Jurnal Pendidikan Karakter, 10(1), 103-118. https://doi.org/https://doi.org/10.21831/jpk.v10i1.28814

Engliana, E., Prasetyo, A., \& Nisa, A. (2021). Empowering young children with folktales and storytelling: A report from a rural West Java village. Asia-Pacific Journal of Research in Early Childhood Education, 15(1), 157-180. https://doi.org/http://dx.doi.org/10.17206/apjrece.2021.15.1.157 157

Hahn, K. K. (2014). A Script-Based Instructional Model of Integrating Language and Culture Education. The Journal of Teaching English Literature.

Harini, S. (2018). IMPLEMENTASI PENDIDIKAN KARAKTER DALAM KURIKULUM 2013. SOSIOHUMANIORA: Jurnal Ilmiah Ilmu Sosial dan Humaniora, 4(2). https://doi.org/10.30738/sosio.v4i2.2982

Undang-Undang Republik Indonesia tentang Sistem Pendidikan Nasional, (2003) (testimony of Dewan Perwakilan Rakyat Republik Indonesia). https://sipuu.setkab.go.id/PUUdoc/7308/UU0202003.htm

Ismaili, M. (2013). The effectiveness of using movies in the EFL classroom-A study conducted at South 
INFERENCE: Journal of English Language Teaching

Vol. 4, No. 3, December 2021 - March 2022

p-ISSN: 2615-8671

e-ISSN: $2615-868 X$

East European University. Academic Journal of Interdisciplinary Studies, 2(4), 121.

Marsh, J. (2014). The Theory of Everything. Universal Pictures.

Miranti, I., Nurjanah, N., \& Dwiastuty, N. (2018). Learning local wisdom for character education: An insight from Choblong Sundanese village in Indonesia. Jurnal Ilmiah Peuradeun, 6(3), 409. https://doi.org/10.26811/peuradeun.v6i3.261

Nurjanah, N., Miranti, I., \& Dwiastuty, N. (2018). Pendidikan karakter dalam kearifan lokal masyarakat Cisarua. Jurnal PkM Pengabdian kepada Masyarakat, 1(01), 32.

https://doi.org/10.30998/jurnalpkm.v1i01.2358

Samuelson, P. L. (2008). Moral imagination in theory and practice. Georgia State University.

Sugiyono. (2009). Metode penelitian kualitatif. Alfabeta.

Suhaidi, M. (2013). Membumikan Pendidikan Karakter Berbasis Nilai Lokal Madura di Perguruan Tinggi. Jurnal Pelopor Pendidikan.

Syarbini, A. (2012). Buku pintar pendidikan karakter. Prima Pustaka.

Tappan, M. B. (1998). Moral education in the zone of proximal development. Journal of Moral Education. https://doi.org/10.1080/0305724980270202

Tmasia, A., \& Serly, Y. (2018). AN ANALYSIS OF POLITENESS AND MAXIM VIOLATED IN “ BLADE RUNNER 2049" FILM. Inference: Journal of English Language Teaching, 1(2), 12-16. https://journal.lppmunindra.ac.id/index.php/inference/article/view/5433/2877 